\title{
Production of biodiesel from vegetable oils and animal fats in waste water
}

- Duong Thi Thanh Thuy

- Pham Trung Kien

Ho Chi Minh City University of Agriculture and Forestry

- Nguyen Van Phuoc

Institute for Environment and Resources, VNU-HCM

- Nguyen Thi Thanh Phuong

University of Technology, VNU-HCM

(Manuscript Received on January 21 ${ }^{\text {st }}, 2013$, Manuscript Revised May 22 ${ }^{\text {nd }}, 2013$ )

\section{ABSTRACT:}

This study was performed to produce biodiesel from vegetable oils and animal fats in waste water of Park Hyatt Saigon hotel. The survey was performed to determine the optimum reaction condition for converting waste grease into biodiesel. The reaction was conducted at 60, 90 and 120 minutes; the catalyst dosage $(\mathrm{NaOH})$ of 2, 3, 4, 5 and
$6 \mathrm{~g}$; ratio of 4:1, 5:1, 6:1, 7:1 $\mathrm{MeOH}:$ grease. The reaction temperature was $60^{\circ} \mathrm{C}$. The optimal reaction conditions were found to be 90 minutes, catalyst dosage of $4 \mathrm{~g}$, ratio of $5: 1 \mathrm{MeOH}$ : grease. The efficient conversion achieved $80 \%$ biodiesel and $20 \%$ crude glycerin.

Keywords: biodiesel, grease, catalyst, glycerin.

\section{INTRODUCTION}

Biodiesel has similar characteristics to diesel fuel, but not made from mineral oil. It is made from vegetable oils or animal fats, be used as diesel fuel.

The use of biodiesel has several advantages over normal diesel, including: easily biodegradable and renewable, so it is an environmentally friendly fuel [1] with lower emissions of $\mathrm{CO}, \mathrm{CO}_{2}$, soot particles and hydrocarbon [2]; relatively high flash point $\left(150^{\circ} \mathrm{C}\right)$ so safety in transport and storage [3]; Biodiesel is better than diesel because it has low in sulfur content, aromatics and a high cetane number [4].
There are three basic methods to biodiesel production: micro-emulsion, pyrolysis (thermal cracking) and transesterification. In particular, the best evaluation is for transesterification because the characteristics of this product are suitable for diesel engines [5].

The transesterification process is the reaction of a triglyceride (fat/oil) with an alcohol to form esters fatty acids and glycerol [5]. This reaction can be carried out with catalyst or not catalyst. When don't use catalyst, the reaction can be carried out by supercritical method [6, 7], or Biox Co-solvent Process. Alkaline [8] and acid [9, 10, 11] or enzyme [5] are the catalysts that can be used in transesterification. However, alkaline is 
more effective than acid in a short time, low reaction temperature. Alkaline can be used with little dosage and it rarely make dark products. Enzyme is too expensive to use for industrialization [5].

There are three kinds of alkaline catalysts: alkaline metals, alkaline oxide or hydroxide. The reaction mechanism for alkaline-catalyzed transesterification was formulated in three steps. The first step is the reaction of the base with the alcohol, producing an alkoxide and the protonated catalyst. The nucleophilic attack of the alkoxide at the carbonyl group of the triglyceride generates a tetrahedral intermediate from which the alkyl ester and the corresponding anion of the diglyceride are formed (Step 2). The latter deprotonates the catalyst, thus regenerating the active species, which is now able to react with a second molecule of the alcohol, starting another catalytic cycle. Diglycerides and monoglycerides are converted by the same mechanism to a mixture of alkyl esters and glycerol. In general, alkaline-catalyzed transesterification processes are carried out at low temperatures and pressures $\left(333-338^{\circ} \mathrm{K}\right.$ and $1.4-$ 4.2 bar) with low catalyst concentrations (0.5-2 wt.\%) [12]. Alkaline metal alkoxides are the most active catalysts because they give very high yield (> 98\%) in short reaction time (30 min) even if they are applied at low molar concentrations $(0.5 \mathrm{~mol} \%)$. However, they require the absence of water so they are inappropriate in industrial processes [13]. Alkaline metal hydroxides $(\mathrm{KOH}$ and $\mathrm{NaOH})$ are cheaper than metal alkoxides, but less active. Nevertheless, they can higher response performance by increasing the catalyst concentration to 1 or $2 \mathrm{~mol} \%$ [13]. Reaction conditions reported in the literature using alkaline catalysts are summarized in Table 1. In most cases, biodiesel production involves the use of methanol and alkaline catalysts. These low cost oils and fats are that they often contain large amounts of free fatty acids that cannot be converted to biodiesel using alkaline catalyst. [14].

Table 1. Summary of some studies using alkaline catalysts

\begin{tabular}{|c|c|c|c|c|c|c|}
\hline Catalyst & Oil & Catalyst (wt.\%) & Temperature $\left({ }^{0} \mathrm{~K}\right)$ & $\begin{array}{l}\text { Reaction time } \\
\text { (h) }\end{array}$ & Yield (\%) & Reference \\
\hline $\mathrm{KOH}$ & Soybean & 0.8 & 313 & 1 & 95 & [15] \\
\hline $\mathrm{NaOH}$ & Sunflower & 1 & 333 & 2 & 97.1 & [16] \\
\hline $\mathrm{NaOCH}_{3}$ & Cotton seed & 0.75 & 338 & 1.5 & 96.9 & [17] \\
\hline $\mathrm{NaOCH}_{3}$ & Rice bran & 0.88 & 328 & 1 & 83.3 & [18] \\
\hline $\mathrm{NaOH}$ & Palm & 1 & 333 & 0.5 & 95 & [19] \\
\hline $\mathrm{KOH}$ & Palm kernel & 1 & 333 & 1 & 96 & [20] \\
\hline $\mathrm{KOH}$ & Sesame oil & 1 & 338 & 1 & 97.6 & [21] \\
\hline $\mathrm{KOH}$ & Waste frying oil & 1.2 & 333 & 2 & 95.8 & [16] \\
\hline
\end{tabular}

\section{MATERIALS AND METHODS}

\subsection{Materials}

Grease was taken from grease trap in the water treatment plant of Park Hyatt Saigon hotel. $\mathrm{NaOH}(96 \%), \mathrm{MeOH}(90 \%) ; \mathrm{Na}_{2} \mathrm{SO}_{4}(96 \%)$ and acetic acid were used as the main reaction chemicals.

\subsection{Experimental set-up and reactor operation}

To achieve purpose of this study, the experiment was conducted as the follows: The reaction time was 60,90 and 120 minutes; the catalyst dosage $(\mathrm{NaOH})$ ranged of 2 to $6 \mathrm{~g}$; volume $\mathrm{MeOH}$ ranged of 400 to $700 \mathrm{~mL}$. The

\section{Trang 6}


reaction temperature was $60^{\circ} \mathrm{C}$. The experiments described in Table 2 .

Table 2. Description of the experiment 1

\begin{tabular}{|c|c|c|c|c|c|}
\hline \multirow{2}{*}{ Grease $(\mathrm{mL})$} & \multirow{2}{*}{$\mathrm{NaOH}(\mathrm{g})$} & \multicolumn{4}{|c|}{ The experiment 1 with the reactor time 60 minutes } \\
\cline { 3 - 6 } & & $\mathrm{MeOH}-400 \mathrm{~mL}$ & $\mathrm{MeOH}-500 \mathrm{~mL}$ & $\mathrm{MeOH}-600 \mathrm{~mL}$ & $\mathrm{MeOH}-700 \mathrm{~mL}$ \\
\hline \multirow{3}{*}{100} & 2 & $\mathrm{TN} 1.2-400$ & $\mathrm{TN} 1.2-500$ & $\mathrm{TN} 1.2-600$ & $\mathrm{TN} 1.2-700$ \\
\cline { 2 - 6 } & \multirow{2}{*}{4} & $\mathrm{TN} 1.3-400$ & $\mathrm{TN} 1.3-500$ & $\mathrm{TN} 1.3-600$ & $\mathrm{TN} 1.3-700$ \\
\cline { 2 - 6 } & 5 & $\mathrm{TN} 1.4-400$ & $\mathrm{TN} 1.4-500$ & $\mathrm{TN} 1.4-600$ & $\mathrm{TN} 1.4-700$ \\
\cline { 2 - 6 } & 6 & $\mathrm{TN} 1.5-400$ & $\mathrm{TN} 1.5-500$ & $\mathrm{TN} 1.5-600$ & $\mathrm{TN} 1.5-700$ \\
\hline
\end{tabular}

The experiments 2 and 3 were similar to the experiment 1 with the reaction time of 90 minutes and 120 minutes.

Operation of transesterification process:

$100 \mathrm{~mL}$ grease was taken into flask, heated to $60^{\circ} \mathrm{C}$, added mixture of $\mathrm{MeOH}$ and $\mathrm{NaOH}$, agitated continuously, and maintained temperature at $60^{\circ} \mathrm{C}$ for 60,90 and 120 minutes. After the reaction ends, product was poured into the separator and settled for 3 hours. The mixture was separated into two phases: ME was pale yellow liquid above, the glycerol was the darker colored liquid on the bottom. The light phase was extracted, neutralized acetic acid and settled for 1 hour. The product after settling was cleaned in warm water and then settle for 30 minutes. Then, the product was dried adding $\mathrm{Na}_{2} \mathrm{SO}_{4}$, used filter paper to separate salt and obtain biodiesel. Washing water and residual $\mathrm{MeOH}$ was taken into flask, heated to $65^{\circ} \mathrm{C} \div 75^{\circ} \mathrm{C}$ to recovery $\mathrm{MeOH}$.

Biodiesel processing equipment is illustrated in the Fig 1.

\subsection{Analysis materials}

Biodiesel samples were analyzed at The Technical Center Standards Measurement Quality 3.
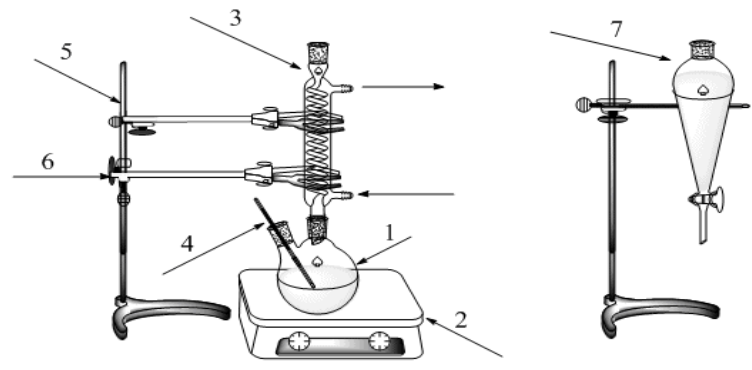

- 1. Flask

- 2. Stirre

- 3. Cryogenic reflux

- 4. Thermometer

- 5. Rest

- 6. Tongs

- 7. Separator

Fig 1. Biodiesel processing equipment 


\section{RESULTS AND DISCUSSION}

The important parameters that influence the production of biodiesel are catalyst dosage, ratio $\mathrm{MeOH}$ : grease, reaction time, etc. Experiments were conducted with different sets of parameter values. From survey results, the optimum condition for biodiesel production will be established.

\subsection{Survey of optimum catalyst dosage $(\mathrm{NaOH})$}

The transesterification reaction requires a catalyst in order to achieve reasonable rates. The effect of catalyst dosage on the reaction efficiency was investigated using $\mathrm{NaOH}$ as a catalyst with dosages changing from 2 to 6 grams.

The study results in Figure 2, 3 and 4 indicate that when increasing catalyst dosage from 2 to 4 grams, the reaction efficiency increased and achieved the highest value at the dose of 4 grams for all experiments. In case of increasing the catalyst dosage above 4 grams, the efficiency reduced because soap formation occurred and tended to increase with higher quantity of catalyst and also backward reaction was favored at thus condition. In addition, according to F. Ma, L. D. Clements, M. A. Hann [22], if more free fatty acids and water exist in the reactants, more $\mathrm{NaOH}$ is needed to neutralize the free fatty acids and react with triglycerides to produce soap [22].

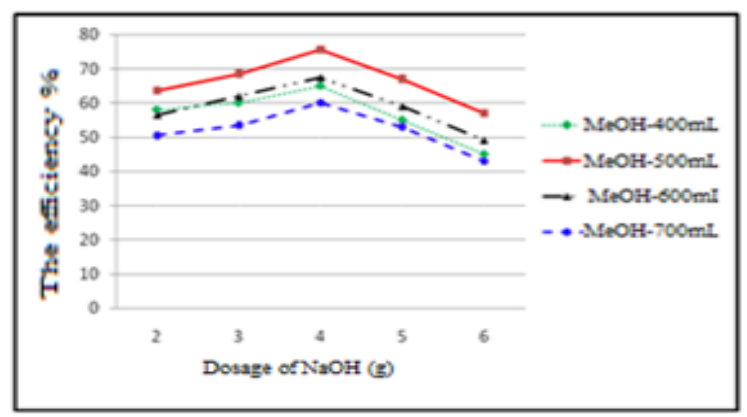

Fig 2. The efficiency of biodiesel in 60 minutes
Similar result was observed by J.M. Marchetti et al, Y. Wang, S. Zhang [23, 24]. It was clear that optimum catalyst dosage $(\mathrm{NaOH})$ was 4 grams.

\subsection{Survey of optimum ratio of $\mathrm{MeOH}$ : grease}

Increasing ratio of $\mathrm{MeOH}$ : grease had a positive effect on the reaction yield as it helped to drive the reaction equilibrium forward. The efficiency increased with an increase ratio of $\mathrm{MeOH}$ : grease from 4:1 to 5:1 but decreased when ratio increased from 5:1 to 7:1 in Fig 2, 3 and 4. Transesterification is an equilibrium reaction in which a large excess of $\mathrm{MeOH}$ is required to drive the reaction to the right. The high molar ratio of $\mathrm{MeOH}$ : grease interfered with the separation of glycerin because there was an increase in solubility. When glycerin remained in solution, it helped drive the equilibrium to back to the left, lowering the efficiency of esters. After the reaction, residual $\mathrm{MeOH}$ created the hydrogen bond with $\mathrm{ME}$ and glycerin. When the volume of the hydrogen bond was too large, it caused the phenomenon of emulsion in product. This phenomenon was difficult for separation and cleaning of product, so the efficiency of biodiesel decreased. Fig 2, 3 and 4 showed the optimum ratio of $\mathrm{MeOH}$ : grease was 5:1. This result was different compared to report of Dr. Lima Rose Miranda (the optimum ratio of 6:1 MeOH:grease [25]).

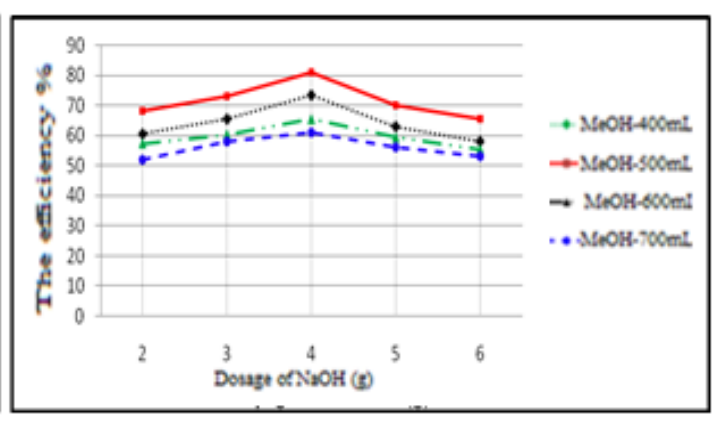

Fig 3. The efficiency of biodiesel in 90 minutes

\section{Trang 8}




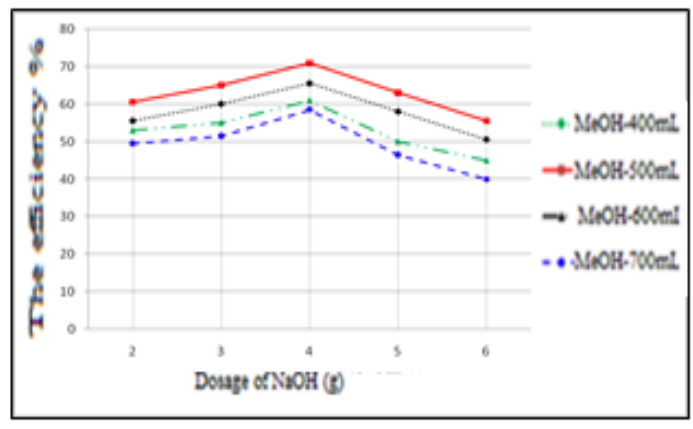

Fig 4. The efficiency of biodiesel in 120 minutes

\subsection{Survey of optimum reaction time}

Effect of reaction time on the efficiency of biodiesel is showed Fig 5. From 60 to 90 minutes, the efficiency of biodiesel increased and achieved the highest value of 90 minutes. When the reaction time was more than 90 minutes, the efficiency decreased because long reaction time at high temperature $\left(60^{\circ} \mathrm{C}\right)$ nearby the boiling point of methanol, so methanol could be easily undergone some loss [27]. In addition, the side effects (saponification or esterification) occurred strongly. The transesterification reaction is reversible. With residual $\mathrm{MeOH}$, the reaction occurred according to the straight direction of motion in a certain period of time and the excess reaction time could not promote the conversion

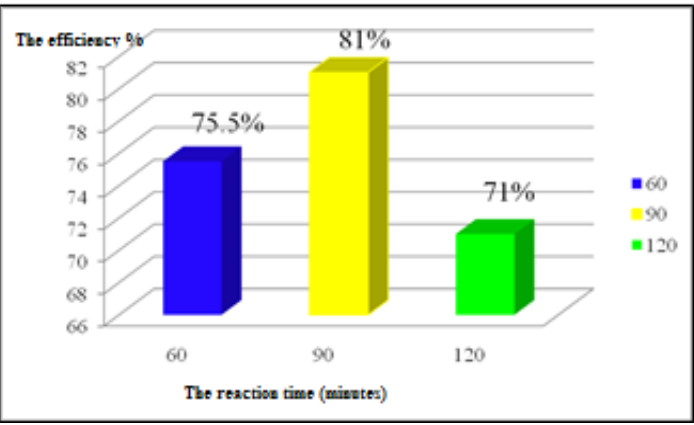

Fig 5. The efficiency in different reaction time

but favored the reverse reaction of transesterification, causing a reduction in the product yield. Similar result was observed by Leung and Guo [26]. It is clear that the optimum reaction time was 90 minutes with the efficiency of $81 \%$. Similar reaction time has been reported in Viet Nam (Le Thi Thanh Huong et al) [27]

\subsection{Characteristics of biodiesel}

Biodiesel product was analyzed at quality assurance and testing center 3 (quatest 3 ).

The analysis results show in Table 3 . Some parameters met Vietnam Standards TCVN 7717:2007 such as acid number, Kinematic viscosity at $40^{\circ} \mathrm{C}$ and density at $115^{\circ} \mathrm{C} / 15^{\circ} \mathrm{C}$.

Table 3. Fuel properties of biodiesel

\begin{tabular}{|l|c|c|c|c|}
\hline \multicolumn{1}{|c|}{ Fuel properties } & Unit & Analysis methods & Result & $\begin{array}{c}\text { TCVN 7717- } \\
2007\end{array}$ \\
\hline Acid number (TAN) & $\mathrm{mgKOH} / \mathrm{g}$ & ASTM D 664 - 07 & 0,3 & 0,5 \\
\hline The flash point with closed cup & ${ }^{0} \mathrm{C}$ & ASTM D 93 - 08 & 18 & $130(\mathrm{~min})$ \\
\hline Kinematic viscosity at $40^{\circ} \mathrm{C}$ & $\mathrm{mm}^{2} / \mathrm{s}$ & ASTM D445 - 06 & 6,031 & $1,9-6,0$ \\
\hline Carbon residue content by mass & $\%$ & $\begin{array}{c}\text { ASTM D4530 - 07 } \\
\text { Micro methods }\end{array}$ & 0,13 & 0,05 \\
\hline Freezing temperatures & ${ }^{0} \mathrm{C}$ & ASTM D 97 - 08 & +9 & - \\
\hline Water content & $\mathrm{mg} / \mathrm{kg}$ & ASTM D 6304 - 07 & 900 & 200 \\
\hline Density at $15^{\circ} \mathrm{C} / 15^{\circ} \mathrm{C}$ & & ASTM D 4052 - 96 (2002) & 0,8838 & - \\
\hline Density at $15^{\circ} \mathrm{C}$ & $\mathrm{kg} / \mathrm{m}^{3}$ & ASTM D 4052 - 96 (2002) & 883,0 & $860-900$ \\
\hline
\end{tabular}





\section{CONCLUSION}

Biodiesel production from waste grease by transesterification with catalyst $\mathrm{NaOH}$ is cheap, safe and high in yield. Results of the study clearly demonstrate that the use of waste grease is very suitable as low cost feed stocks for biodiesel production. The optimum reaction conditions were determined the reaction time 90 minutes, catalyst dosage of $4 \mathrm{~g}$, ratio of $5: 1$ $\mathrm{MeOH}$ : grease; the efficiency for biodiesel was $80 \%$ and $20 \%$ for crude glycerin. Biodiesel is a new alternative transportation fuel, whereby reduce the amount of grease discharged to the environment and also to reduce the imported fuel oil, and bring economic benefit. However, more research is needed to improve the quality of biodiesel.

Acknowledgements: This study was supported by Institute for Environment and Resource - Vietnam National University Ho Chi Minh City.

\section{Nghiên cứu sản xuất Biodesel từ dầu mỡ động thực vật}

- Dương Thị Thanh Thủy

- Phạm Trung Kiên

Trường Đại học Nông Lâm Tp.HCM

- Nguyễn Văn Phước

Viện Môi trường và Tài nguyên, ĐHQG-HCM

- Nguyễn Thị Thanh Phượng

Trường Đại học Bách khoa, ĐHQG-HCM

\section{TÓM TÁ́T:}

Nghiên cứu sản xuất biodesel từ dầu mỡ động thực vật được thực hiện trên nước thải của khách sạn Park Hyatt Saigon. Nội dung nghiên cứu nhằm tìm ra điều kiện tối ưu cho phản ứng chuyển hóa dầu mỡ thải thành biodiesel. Trong đó, các yếu tố cần khảo sát là: Thời gian phản ứng 60, 90 và 120 phút, hàm lượng chất xúc tác kiềm $(\mathrm{NaOH})$ là 2, 3, 4, 5, 6 gam, tỉ lệ mol MeOH:dầu mõ là 4:1,

5:1, 6:1, 7:1. Nhiệt độ phản ứng được cố định ở $60^{\circ} \mathrm{C}$. Kết quả nghiên cứu trong điều kiện PTN đã xác định thời gian tối ưu cho phản ứng là 90 phút với hàm lượng xúc tác $4 g$ và tỷ lệ $\mathrm{mol} \mathrm{MeOH}$ :dầu mõ là 5:1. Phần dầu mỡ động thực được thu hồi từ nước thải có thể chuyển hóa thành biodiesel với hiệu xuất $80 \%$, và $20 \%$ glycerin thô.

Từ khóa: biodiesel, dầu mõ', glycerin, chất xúc tác. 


\section{REFFERENCES}

[1]. Demirbas A. Biodegradability of biodiesel and petrodiesel fuels. Energy Sour, Part A: Recov Utiliza Environ Effects 2009; 31:169-74.

[2]. Yee KF, Tan KT, Abdullah AZ, Lee KT. Life cycle assessment of palm biodiesel: revealing facts and benefits for sustainability. Appl Energy 2009; 86:18996.

[3]. S. Lee, D. Posarac, N. Ellis. An experimental investigation of biodiesel synthesis from waste canola oil using supercritical methanol. Fuel 91 2012: 229237

[4]. Martini N, Schell S. Plant oil as fuels: present state of future developments. In: Proceedings of the synopsis. Portdam, Germany, Berlin: Springer; 1998. p. 6.

[5]. Mustafa Balat*, Havva Balat. Progress in biodiesel processing. Applied Energy 2010; 87: $1815-1835$

[6]. Prafulla Patil, Shuguang Deng, J. Isaac Rhodes, Peter J. Lammers. Conversion of waste cooking oil to biodiesel using ferric sulfate and supercritical methanol processes. Fuel 89, 2010:360-364

[7]. S. Lee, D. Posarac, N. Ellis. An experimental investigation of biodiesel synthesis from waste canola oil using supercritical methanol. Fuel 91, 2012: 229237

[8]. Freedman B, Pryde EH, Mounts TL. Variables affecting the yields of fatty esters from transesterified vegetable oils. J Am Oil Chem Soc 1984;61:1638-43

[9]. Gao C, Zhai Y, Ding Y, Wu Q. Application of sweet sorghum for biodiesel production by heterotrophic microalga Chlorella protothecoides. Appl Energy 2010;87:75661.
[10]. Li Y, Zhang XD, Sun L, Zhang J, Xu HP. Fatty acid methyl ester synthesis catalyzed by solid superacid catalyst $/ \mathrm{ZrO}_{2}-\mathrm{TiO}_{2} / \mathrm{La}^{3+}$. Appl Energy 2010;87:156-9.

[11]. Miao X, Li R, Yao H. Effective acidcatalyzed transesterification for biodiesel production. Energy Convers Manage 2009;50:2680-4.

[12]. Lotero E, Goodwin JG, Bruce DA, Suwannakarn K, Liu Y, Lopez DE. The catalysis of biodiesel synthesis. Catalysis 2006;19:41-83.

[13]. Schuchardt U, Sercheli R, Vargas RM. Transesterification of vegetable oils: a review. J Braz Chem Soc 1998;9:199-210

[14]. Canakcı M, Van Gerpen J. Biodiesel production from oils and fats with high free fatty acids. Trans ASAE 2001;44:1429-36.

[15]. Zagonel GF, Peralta-Zamora PG, Ramos LP. Production of ethyl esters from crude soybean oil: optimization of reaction yields using a 23 experimental design and development of a new analytical strategy for reaction control. Preprints Symp: Am Chem Soc Div Fuel Chem 2002;47:363-4.

[16]. Dias JM, Alvim-Ferraz MCM, Almeida MF. Comparison of the performance of different homogeneous alkali catalysts during transesterification of waste and virgin oils and evaluation of biodiesel quality. Fuel 2008;87: 3572-8.

[17]. Rashid U, Anwar F, Knothe G. Evaluation of biodiesel obtained from cottonseed oil. Fuel Process Technol 2009;90:1157-63.

[18]. Rashid U, Anwar F, Ansari TM, Arif M, Ahmad M. Optimization of alkaline transesterification of rice bran oil for biodiesel production using response surface methodology. J Chem Tech Biotechnol 2009;84:1364-70. 
[19]. Lubes ZIZ, Zakaria M. Analysis of parameters for fatty acid methyl esters production from refined palm oil for use as biodiesel in the single- and twostage processes. Malaysian J Biochem Mol Biol 2009;17:5-9.

[20]. Alamu OJ, Waheed MA, Jekayinfa SO, Akintola TA. Optimal transesterification duration for biodiesel production from Nigerian palm kernel oil. Agri Eng Int CIGR Ejournal 2007;IX:1-11.

[21]. El Diwani G, Attia NK, Hawash SI. Development and evaluation of biodiesel fuel and by-products from jatropha oil. Int J Environ Sci Technol 2009;6:219-24.

[22]. F. Ma, L. D. Clements, M. A. Hanna. The Effects of Catalyst, Free Fatty Acids, and Water on Transecterification of Beef Tallow 1998. 41(5): 1261-1264

[23]. J.M. Marchetti, V.U. Miguel and A.F. Errazu, Heterogeneousesterification of oil with high amount of free fatty acids, Fuel 86 (2007), pp. 906-910

[24]. Y. Wang, S. Ou, P. Liu and Z. Zhang, Preparation of biodiesel fromwaste cooking oil via two-step catalyzed process, Energy Convers Manage 48 (2007), pp. 184-188

[25]. Dr. Lima Rose Miranda, Poultry Fat-A Cheap and Viable Source for Biodiesel Production, International Conference on Environmental Science and Technology IPCBEE vol.6 (2011)

[26]. D.Y.C. Leung, Y. Guo, Transesterification of neat and used frying oil: optimization for biodiesel production, Fuel Process. Technol. 87 (2006) 883-890.

[27]. Le Thi Thanh Huong, Huynh Van Tien, Phan Minh Tan, Calcium oxide as a solid base catalyst for transesterification of tra catfish fat. Tap chi phat trien $\mathrm{KH} \& \mathrm{CN}$ 17(2009) 